\title{
CRIME POLÍTICO E EXTRADIÇÃO: A QUESTÃO DA EXTRADIÇÃO POLÍTICA DISFARÇADA
}

\author{
Angela Jank Calixto ${ }^{1}$ \\ Rejane Alves de Arruda ${ }^{2}$
}

RESUMO: Objetiva-se demonstrar como são formulados os pedidos de extradição política disfarçada e o porquê da impossibilidade de extradição nos casos em que verificados. Efetuada uma análise, através do método dedutivo, da origem e fundamentos da cláusula de inextraditabilidade ante o cometimento de crimes políticos, do conceito conferido a referidos crimes e das circunstâncias consideradas pelo STF para concluir pela existência de pedido de extradição política disfarçada na Extradição no $n^{\circ}$ 794/Paraguai, verificou-se haver uma preocupação dos juristas brasileiros em evitar a perseguição política, em consonância com as garantias fundamentais consagradas pela $\mathrm{CF}$ e com as normas internacionais que regem a matéria.

PALAVRAS-CHAVE: Extradição política disfarçada; Crimes políticos; Extradição $\mathrm{n}^{\circ}$ 794/Paraguai; Direitos Fundamentais; Cláusula de Inextraditabilidade.

\section{POLITICAL CRIMES AND EXTRADICTION: THE ISSUE CONCERNING DISGUISED POLITICAL EXTRADITION}

\begin{abstract}
This article seeks to demonstrate how requests of disguised political extradition occur and why extradition is not possible in such cases. After effectuating an analysis, through the deductive method, of the origin and fundaments of the non-extradition clause in case of political crimes, of the concept given to such crimes and of the circumstances considered by the Brazilian Supreme Court to conclude for the existence of disguised political extradition in Extradition No. 794/Paraguay, it was found that Brazilian jurists are concerned in avoiding political persecution, in consonance with fundamental guarantees consecrated in the Brazilian Federal Constitution and with international norms.
\end{abstract}

KEYWORDS: Disguised political extradition; Political crimes; Extradition n. 794/Paraguay; Fundamental Rights; Non-extradition clause.

\footnotetext{
${ }^{1}$ Doutoranda em Direito do Estado pela USP. Mestre em Direitos Humanos pela UFMS. Especialista em Direito Público. Segunda Vice-Presidente da Federação Nacional dos Pós-graduandos em Direito (FEPODI). Assistente Editorial Revista Direito UFMS. angelajcalixto@gmail.com

2 Advogada. Doutora e Mestre em Direito pela PUC/SP. Especialista em Direito Penal Econômico pela Universidade de Coimbra. Professora da UFMS e UCDB, em Mato Grosso do Sul. Rejane.arruda @ hotmail.com
} 


\section{INTRODUÇÃO}

O desenvolvimento tecnológico e industrial e o processo de integração por que passa o mundo globalizado têm conduzido ao aumento do fluxo migratório de pessoas, seja este decorrente de fatores econômicos, ambientais, políticos ou sociais. Dentre os diversos processos migratórios existentes, verifica-se, em especial, um aumento do fluxo de pessoas que perpassam as fronteiras de seu país para refugiar-se, para pleitear asilo político, ou simplesmente para buscar furtar-se de eventual responsabilização penal a que estaria subjugado ante o cometimento de determinado delito no país de origem.

Ante a busca de se garantir a punição de agentes que após cometerem crimes em determinado país fogem para outro, na tentativa de esquivar-se da imputação penal, desenvolveu-se nas legislações pátrias e em tratados internacionais a possibilidade de se solicitar a extradição de referidos agentes para o país no qual houve a prática do crime. Tratase de um instituto de cooperação internacional entre Estados, com o fim primordial de se garantir a repressão da criminalidade.

Salienta-se, entretanto, que o desenvolvimento do instituto da extradição ao longo dos anos levou à fixação de limites ao processo extradicional, dentre eles destacando-se vedação à extradição de agentes acusados do cometimento de crimes de caráter político, vedação esta prevista, inclusive, como direito fundamental na Carta Magna brasileira.

Em razão da aceitação universal do princípio da inextraditabilidade de delinquentes políticos, verifica-se que muitos Estados, com o fim primordial de assegurar a concessão da extradição, formulam o pedido de extradição sob o argumento de que apenas houve a prática de crime comum em seu território, dissimulando na realidade uma situação de perseguição política. Trata-se da denominada "extradição política disfarçada", introduzida na doutrina brasileira a partir dos ensinamentos lançados pelo Ministro Sepúlveda Pertence, em 1980, o qual defende a necessidade primordial de se erradicar tal prática, qual seja, de se buscar perseguir criminalmente agentes tão somente em razão de serem considerados inimigos políticos de um governo, para que assim se cumpra o mandamento constitucional.

Ante tal situação, compete ao Supremo Tribunal Federal, órgão responsável pela análise dos pedidos de extradição, verificar no caso concreto se efetivamente é legítimo o pedido de extradição formulado, ou se, em sendo contrário, o que se verifica é um pedido de extradição política disfarçada, o que implicaria a denegação da ordem de extradição, como o 
fez no processo de Extradição $n^{\circ}$ 794/Paraguai, caso este de extrema relevância para o desenvolvimento do conceito de extradição política disfarçada na doutrina brasileira.

Diante da importância de se compreender de que modo se dá a extradição política disfarçada, bem como o porquê da impossibilidade de extradição nos casos em que verificada, torna-se necessário um estudo mais aprofundado acerca do tema, de modo a identificar o respeito ao mandamento constitucional e às normas internacionais, as quais vedem toda e qualquer forma de perseguição política no cenário internacional.

Para tanto, será analisada, em um primeiro momento, a evolução histórica do conceito de extradição e da impossibilidade de seu deferimento no caso do cometimento de delitos políticos, para que se possa compreender os motivos pelos quais a extradição, nessas hipóteses, não é autorizada. Após, serão apresentadas as dificuldades concernentes à definição de crime político, com o fim primordial de se compreender qual a visão do STF no tocante à temática, já que este se configura como o órgão responsável pela definição do conceito.

Por fim, adentrar-se-á mais especificamente no tema, discorrendo-se acerca da extradição política disfarçada e em que situações esta se encontra configurada e efetuando-se um estudo aprofundado do processo de Extradição n ${ }^{\circ}$ 794/Paraguai (Caso Oviedo), caso este paradigmático no Brasil para a compreensão do instituto da extradição política disfarçada.

Com relação ao procedimento metodológico, será realizada, quanto aos fins, uma pesquisa exploratória e descritiva, já que se buscará apresentar um panorama geral acerca do instituto da extradição, do conceito de crime político e da extradição política disfarçada, sendo utilizado, para tanto, o método dedutivo. Quanto aos meios, será realizada, além de um estudo de caso (Extradição no 794/Paraguai), uma pesquisa bibliográfica e documental, a partir de material coletado essencialmente de livros, artigos científicos, dissertações e revistas científicas.

\section{EVOLUÇÃO HISTÓRICA DA EXTRADIÇÃO E DA IMPOSSIBILIDADE DE SEU DEFERIMENTO NO CASO DE CRIME POLÍTICO}

Diante da preocupação internacional no combate à criminalidade, preocupação essa derivada, na atualidade, do processo de integração por que passa o mundo globalizado e, consequentemente, do aumento do fluxo migratório de pessoas, o processo de extradição surge como forma de garantir a punição de agente que transpassa as fronteiras do território do país no 
qual cometeu certo delito, com o fim primordial de furtar-se de sua responsabilidade penal ante o delito cometido.

Como afirma Macabu (1980, p. 153), “atualmente, a extradição desperta um interesse considerável, numa época em que os meios modernos de comunicação tornam o deslocamento dos indivíduos extremamente fácil e as distâncias deixam de ser um óbice à circulação rápida e em massa dos seres humanos".

O surgimento e desenvolvimento do processo de extradição justificam-se, pois, conforme pontuado por Accioly (2016), ante o interesse pela consagração da justiça natural, ou seja, pela busca de se garantir que um indivíduo não se subtraia das consequências do delito cometido; diante do dever de solidariedade e de assistência mútua entre os Estados contra a prática de crimes; e em razão do interesse dos Estados de manutenção da ordem social. Além disso, deriva do respeito ao princípio da soberania dos Estados, o qual impede que um Estado interessado na persecução penal de um indivíduo invada o território de outro Estado soberano com o objetivo de garantir a punição do agente infrator (CONTESSA, 2011).

Segundo definição apresentada por Rezek (2011, p. 230), a extradição consiste na “entrega, por um Estado a outro, e a pedido deste, de pessoa que em seu território deva responder a processo penal ou cumprir pena", correspondendo a um importante instrumento de cooperação internacional entre Estados, destinado à repressão da criminalidade.

Trata-se de um ato fundamentado em tratado ou na promessa de reciprocidade existente entre o país que solicita a extradição e o país no qual se encontra o extraditando, o qual analisa a presença ou não de todos os pressupostos necessários para a entrega da pessoa reclamada.

No direito brasileiro, o instituto da extradição encontra-se regulado no art. $5^{\circ}$, LI e LII, da Constituição de 1988, na Lei $n^{\circ}$ 6.815/80 (Estatuto do Estrangeiro) e no Decreto $\mathrm{n}^{\circ}$ $86.715 / 1981$, nos quais são prescritos os pressupostos objetivos para que seja possível a concessão da extradição e as hipóteses em que esta deverá ser denegada pelo Supremo Tribunal Federal, órgão este responsável pela análise da legalidade da entrega do extraditando ao Estado solicitante.

Dentre os pressupostos para a concessão da extradição, destaca-se que referidos diplomas legais preveem que além da necessidade de que o delito também seja considerado um crime no Brasil, que a lei brasileira imponha ao crime pena de prisão igual ou inferior a um ano, que a punibilidade não esteja extinta penal prescrição, que o extraditando não tenha que responder perante Tribunal ou juízo de exceção, que o reclamado não seja brasileiro nato ou 
naturalizado (exceto nas hipóteses expressamente previstas no art. $\left.5^{\circ}, \mathrm{LI}, \mathrm{da} \mathrm{CF}\right)^{3}$, entre outros, também não será permitida a entrega do reclamado no caso de o delito por ele cometido no território solicitante seja pelo STF considerado crime político.

Para que se possa entender o porquê de ter-se firmado, ao longo da história, o entendimento de que não será possível que se autorize a extradição no caso de cometimento de crime político, é necessário que seja efetuado um breve escorço histórico acerca do desenvolvimento do instituto da extradição no cenário global e no Estado brasileiro.

Em que pese o fato de a extradição ter surgido desde o período antigo, tendo sido consagrada precipuamente em 1291 a.C, no Egito, a partir da conclusão de um dos mais antigos tratados de paz entre Ramsés II e Hattisuli III, no qual se dispôs expressamente acerca do retorno de pessoas procuradas por seus soberanos que tinham se refugiado para outros territórios (MACABU, 1980), é certo que não possuía ela as mesmas características que hoje apresenta. De modo contrário ao hoje estipulado, apenas se previa a possibilidade de extradição de criminosos políticos e não do criminoso comum (MELLO, 2002).

A extradição desenvolveu-se lentamente ao longo dos séculos, Mello (2002) destacando que é possível verificar sua prática na Grécia e Roma antigas, nas quais se previa a possibilidade de extradição em caso de cometimento de crimes graves e, em especial, no caso de se atentar contra o governo ou o soberano; na Idade Média, na qual foram celebrados inúmeros acordos de extradição, como o acordo Lotário com Veneza, em 840, e o acordo de extradição entre a Inglaterra e a Escócia, em 1174, entre outros; e na Idade Moderna (séculos XVI, XVII e XVIII), nos quais a extradição passa a se caracterizar pela entrega de criminosos militares (para se evitar deserções) e para a defesa dos regimes então vigentes.

O que se vislumbra como ponto em comum entre essas fases é que a extradição era um mecanismo pelo qual se assegurava a perseguição política dos inimigos políticos do governo, seja este o populos romanos, seja este o Rei ou o soberano, de modo que não se permitia a concessão de refúgio a um acusado de "traição" ou e ofensa ao chefe de Estado de outro país. Até o início do século XVIII, não havia que se falar na entrega de criminosos em razão do cometimento de crime comum, mas sim na "extradição dos rebeldes e dos criminosos políticos, o que prova que os reis eram mais ciosos de sua segurança pessoal e da defesa de seu poder do

\footnotetext{
${ }^{3} \mathrm{O}$ art. $5^{\circ}$, LI, da CF, dispõe que "nenhum brasileiro será extraditado, salvo o naturalizado, em caso de crime comum, praticado antes da naturalização, ou de comprovado envolvimento em tráfico ilícito de entorpecentes e drogas afins, na forma da lei".
} 
que do perigo social que representava para os súditos a impunidade dos criminosos" (MACABU, 1980, p. 147-148).

É somente a partir do final do século XVIII que a extradição passa a ser concebida como uma forma de cooperação internacional, não mais sendo ela direcionada à punição de criminosos políticos. Nesse sentido, discorre Contessa (2011, p. 14-15):

Com a reforma protestante e com as revoluções liberais e industrial, deu-se o fim da supremacia ideológica da religião católica e das monarquias absolutas e o aumento do fluxo de pessoas entro os Estados, levando à necessidade de maior controle da criminalidade comum, em detrimento do enfoque antes dado principalmente aos criminosos políticos. O seu desenvolvimento deu-se especialmente em razão das ocorrências políticas na França e à atuação de sua diplomacia, a qual foi responsável por desenvolver os princípios característicos da extradição moderna, tais como nacionalidade, prescritibilidade, especialidade e, enfim, a exceção à extradição de criminosos políticos [...].

Ademais, ressalta-se que somente a partir de 1791 passa-se a utilizar a palavra “extradição" para designar essa entrega de um indivíduo para outro Estado solicitante, ou seja, como um mecanismo de cooperação internacional destinado o preservar os interesses dos povos.

Desse modo, após a Reforma Protestante, a Revolução Industrial e, em especial, a Revolução Francesa (1789-1799), a divergência de opiniões e de ideologias políticas passa a ser finalmente tolerada. Isso se deve, por um lado, ao fim da hegemonia ideológica e ao desenvolvimento de um pluralismo político e religioso na região, e, por outro lado, ao aumento da mobilidade individual proporcionado pela revolução industrial, o que permitiu que os acusados de crimes comuns se locomovessem para além das fronteiras do Estado em que houve a prática do crime (TIBURCIO; BARROSO, 2001).

Assim, há uma redefinição do conceito de crime político, o qual deixa de ser considerado uma traição ao governante, para constituir apenas um crime contra a segurança do Estado.

Nesse cenário, os ideias liberais de oferta de asilo político passaram a ser disseminados pela Europa, destacando-se a consagração do princípio da concessão de asilo política na França em 1831, através de uma circular que continha a declaração do governo de que não mais seria concedida a extradição em razão de crime político, e da positivação na Lei Belga, em 1833, da impossibilidade de extradição em caso de cometimento de crime político (CONTESSA, 2011). 
É importante ressaltar que a principal justificativa para se excluir os crimes políticos do escopo da extradição consiste na política eminentemente liberal das novas democracias que surgiram com referidas transformações políticas, "as quais passaram a admitir o dissenso político e a refutar a possibilidade de perseguição em razão da ideologia ou opinião do agente" (CONTESSA, 2011, p. 18). Ainda, como pontuado por Mello (2002) pode-se afirmar que a não extradição em caso de prática de crime político também é justificada em razão de o aspecto antissocial do crime ser relativo, de se vislumbrar que o criminoso político não teria em seu país um julgamento imparcial e ante a aplicação do princípio da não intervenção nos assuntos de um Estado estrangeiro.

Destaca-se a explicação fornecida por Tiburcio e Barroso (2001, p. 177):

A exceção do crime político é justificada por vários fundamentos, o que acaba
tornando a questão mais complexa. O primeiro baseia-se no conceito de que
os Estados não devem se imiscuir nas atividades internas dos demais, e a
extradição de criminosos políticos significaria um parti pris do Estado
concedente em face do Estado requerente. Pondera-se ainda que, embora o
crime político seja contrário à moral, este se justificaria pelas circunstâncias
do momento. Além disso, vale lembrar que o acusado de crime político tem
mais chances do que o criminoso comum de ser submetido a julgamentos
injustos ou a outras violações de direitos fundamentais básicos.

Como bem conclui Zanotto (2015, p. 76), a cláusula de inextrabilidade de pessoa condenada pelo cometimento de crime político, além de derivar a impossibilidade de ingerência estatal externa nas questões políticas de outros Estados, está essencialmente embasada "no pluralismo político, no reconhecimento da legítima divergência ideológica, na relatividade da infração política, na impossibilidade de se conferir ao extraditando julgamento imparcial na jurisdição do Estado requerente".

É diante de tais justificativas que não se entende ser mais concebível, atualmente, a extradição de pessoas em razão do cometimento de crime político, a concessão de asilo político constituindo a regra. Nesse sentido é que a Constituição Federal brasileira prevê expressamente em seu art. $5^{\circ}$, LII, a impossibilidade de extradição ante o cometimento de crime político, tratando-se de um direito fundamental protegido tanto pelo Estado brasileiro quanto pelo ordenamento jurídico internacional. 


\section{O CONCEITO DE CRIME POLÍTICO: A VISÃO DA DOUTRINA E DO SUPREMO TRIBUNAL FEDERAL}

O ordenamento jurídico brasileiro se pauta, no âmbito do processo extradicional, pela denegação do pedido de extradição no caso de o reclamado ser pessoa envolvido na prática de crime político. A inextraditabilidade de estrangeiros por delitos políticos reflete uma tradição constitucional republicana, tendo sido primeiramente prevista na Constituição de 1934, posteriormente sido suprimida pela Carta de 1937, restaurada pela Constituição de 1946 e mantida pelas Constituições de 1967 e de 1969 (BRASIL. Supremo Tribunal Federal, 1990).

Atualmente, como já destacado, a impossibilidade de extradição de pessoa acusada do cometimento de crime político encontra-se prevista no art. $5^{\circ}$, LII, da CF, além de também haver sua previsão e regulamentação no art. 77, VII, da Lei n 6.815/80.

No entanto, em que pese a previsão de referida impossibilidade, a legislação brasileira não oferece um conceito preciso acerca do que se configuraria como crime político, apenas estabelecendo no $\S 2^{\circ}$ do art. 77 do Estatuto do Estrangeiro que "caberá, exclusivamente, ao Supremo Tribunal Federal, a apreciação do caráter da infração”. Dessa forma, a qualificação da natureza do crime como político cabe precipuamente ao STF, responsável por, quando da análise do caso concreto e com base nas doutrinas existentes no tocante ao tema em voga, destacar as principais circunstâncias que permitem qualificar o crime como político.

Insta esclarecer que apesar de os crimes políticos possuírem um grande papel na vida civil e no tocante às preocupações do público, a noção do conceito de crime político até hoje resta vaga e imprecisa (LÉVY-BRUHL, 1964). Isso porque sua definição depende mais da prevalência de uma ideologia política majoritária do que da dogmática penal (FRAGOSO, 1980), o que torna a definição de crime político extremamente dificultosa.

Em que pese a vagueza, procura-se estabelecer, na doutrina e jurisprudência, uma definição para crimes políticos. Salienta-se o entendimento exarado pelo ministro Djaci Falcão quanto à definição do conceito:

Em nosso direito positivo não há uma definição de crime político. Aliás, o conceito de crime político é controvertido e variável, porquanto não é fácil dizer do seu conteúdo e limites, no tempo e no espaço. Não resta dúvida, porém, que no seu conceito são incluídos os delitos que atingem a estrutura política do Estado, as suas instituições públicas, a sua independência (BRASIL. Supremo Tribunal Federal, 1980, p. 24). 
Já Hungria (1955, p. 181) define crimes políticos como "atos dirigidos, subjetiva e objetivamente, de modo imediato, contra o Estado como unidade orgânica das instituições políticas e sociais”. Ressalta-se, ainda, o posicionamento de Cândido Motta (1930, p. 20), o qual salienta que os crimes políticos são aqueles que ofendem a ordem política do Estado, "quer seja esta externa, como a independência da Nação, a integridade territorial, as relações entre duas ou mais nações; quer seja interna, como a fórma de governo, a organização e o funccionamento dos poderes políticos e dos direitos políticos dos cidadãos”.

Ante a inexistência de uma norma legal definidora de crime político, a doutrina ainda é pouco precisa ao fixar o conceito de crime político. Pode-se afirmar, entretanto, que no geral a doutrina, na tentativa de balizar os limites precisos dos delitos políticos, classifica os crimes políticos segundo três diferentes critérios, quais sejam, o objetivo, o subjetivo e o misto.

Para a teoria objetiva, a definição de certa ação como crime político é realizada a partir da definição de qual bem jurídico é lesado ou ameaçado, entendendo-se como crime político aquele "dirigido contra a ordem política do Estado, seja esta externa ou interna, ou contra os direitos de seus cidadãos" (CONTESSA, 2011, p. 22). Este é o posicionamento adotado por Fragoso (1980, p. 140), o qual entende que os crimes políticos são aqueles que "ofendem interesses políticos do Estado (próprios do Estado, como tal, ou seja, interesses que se relacionam com a vida do Estado na sua essência unitária, como a integridade do território, independência, honra, forma de governo, etc.)".

O critério objetivo não corresponde ao critério utilizado pelo STF para analisar, no caso concreto, se o delito cometido pelo extraditando pode ser conceituado como crime político, o Tribunal Supremo adotando como a teoria mista na maior parte dos casos submetidos a sua apreciação.

Em que pese tal fato, referido critério foi o utilizado para se denegar a extradição no Caso Shaab (Extradição $\mathrm{n}^{\circ}$ 700), no qual o reclamado Karl-Heinz Shaab foi acusado de transmitir, sem autorização, segredos do Estado alemão, concernentes a construções, projetos e equipamentos utilizados para o enriquecimento de urânio, para colaboradores do programa nuclear da República do Iraque. Na hipótese, os ministros do STF divergiram da opinião majoritária da doutrina, já que, ignorando o critério subjetivo, concederam asilo político ao reclamado sob a alegação de sua impossibilidade, diante do fato de o bem jurídico lesado ter sido a segurança do Estado, o que caracterizaria o crime como político (BRASIL, Supremo Tribunal Federal, 1998). 
Em sentido contrário, a teoria subjetiva fundamenta-se no elemento subjetivo do crime, ou seja, na intenção do agente ao praticar o delito, não importando o bem jurídico efetivamente atingido pelo delito. Dessa forma, para essa teoria, "não importa que a conduta constitua crime comum: uma vez impulsionada por motivos políticos, tem-se como perfeitamente caracterizado o delito político" (PRADO; CARVALHO, 2000, p. 438).

Por fim há ainda a teoria mista, a qual pontua que as duas anteriormente retratadas são insuficientes para adequadamente explicar o que é um crime político, devendo-se considerar, na conceituação, tanto o bem jurídico afetado quanto as intenções políticas do agente. Este é o posicionamento de Lévy-Bruhl (1964), segundo o qual deve ser entendido como crime político a infração que busca reformular a ordem política, social e religiosa, sendo o agente infrator movido por interesse político diverso de seu próprio interesse individual.

Do mesmo modo é o entendimento de Pedro Nunes, o qual conceitua crime político como "toda ação subversiva, inspirada em propósito político elevado e nobre, que vise o bem comum, ou da pátria, ou de que resulte violação à segurança das instituições nacionais, ou da ordem política e social, alcançando direta e especificamente a organização política do Estado”, este representado por qualquer dos órgãos que o integram (NUNES apud FERREIRA, 1989, p. 174).

Atualmente, a doutrina majoritária defende que para a caracterização do crime político é necessário que se sopese, ao mesmo tempo, o elemento subjetivo da conduta e o bem jurídico lesado ou ameaçado de lesão, predominando, pois, a adoção do critério misto para a definição do que seja crime político (PRADO; CARVALHO, 2000).

Do mesmo modo, a teoria mista é a predominantemente utilizada pelos Ministros do Supremo Tribunal Federal para a análise do caráter político do crime imputado ao extraditando.

É possível vislumbrar em diversos votos expressa menção à teoria mista, os ministros levando em consideração tanto aspectos objetivos quanto subjetivos quando da análise do caso concreto submetido a sua apreciação. Nesse sentido, destaca-se o voto proferido pelo ministro Aldir Passarinho na análise da Extradição n 417, o qual ressaltou que "o crime será político ou não pela motivação do agente e aos fins que visa. O crime é político ou não pelas características que o envolvem. Ele é, ou não é, substancialmente” (BRASIL. Supremo Tribunal Federal, 1984, p. 52), de modo que considerou que, no caso, era inquestionável o caráter político dos crimes cometidos pelo extraditando.

No caso La Tablada (Extradição 493) o STF também levou em consideração a teoria mista para denegar a extradição à República Argentina, uma vez que verificou que os crimes 


\section{CRIME POLÍTICO E EXTRADIÇÃO: A QUESTÃo DA EXTRADIÇÃo POLÍTICA DISFARÇADA}

cometidos pelo reclamado, o Sr. Fernando Carlos Falco, o qual havia invadido o quartel de $\mathrm{La}$ Tablada, além de deterem claro caráter político, também foram cometidos segundo objetivo eminentemente político, qual seja, alterar a vigência das instituições estabelecidas pela Constituição Federal. Nesse sentido, destaca-se o voto proferido pelo Ministro Sepúlveda Pertence, o qual, esclareceu em que sentido encontravam-se presentes tanto o critério objetivo quanto o critério subjetivo para a caracterização do delito como político:

O objeto jurídico do delito - a vigência da Constituição Nacional -, já o faz crime político, em qualquer hipótese. Igualmente manifesta é a natureza política da rebelião agravada, em que se capitulou, no caso, a tresloucada invasão do quartel de La Tablada. Objetivamente, a rebelião ou insurreição é crime político por excelência [...].

Também sob o prisma da motivação do fato concreto, critério objetivo de sua identificação, a natureza política da disparata aventura vanguardista de $L a$ Tablada é irrecusável (BRASIL. Supremo Tribunal Federal, 1989, p. 46-49).

De igual forma, seguindo a orientação dada a partir do julgamento do caso La Tablada, temos o Caso Medina (Extradição 1008/Colômbia), a partir da qual se sedimentou a possibilidade de se reconhecer como delito político atos atentatórios à ordem pública, mesmo que praticados com violência. Ainda, verifica-se a adoção da teoria mista para justificar a concessão ou denegação da extradição em diversos outros pronunciamentos do Supremo, como nas Extradições nº 446, 347, 694, entre outras.

Dessa forma, denota-se a predominância da teoria mista, levando-se em consideração, pois, para a análise do pedido de extradição, não somente o objeto do crime perpetrado, mas também o intento do autor na prática do crime.

A adoção de referida teoria é de essencial importância, pois permite a extensão, quando da análise do pedido de extradição, do caráter de crime político a crimes comuns praticados pelo agente infrator, ao contrário do determinado pela teoria objetiva, já que considera o objetivo visado pelo agente quando da prática do crime (consoante a teoria subjetiva). Do mesmo modo, permite ao Tribunal Superior, na análise do caso concreto, denegar a extradição quando verificada a ocorrência de pedido de extradição política disfarçada, como se verá com mais afinco na próxima seção deste trabalho. 


\section{A QUESTÃO DA EXTRADIÇÃO POLÍTICA DISFARÇADA E O JULGAMENTO DO CASO OVIEDO (EXTRADIÇÃO Nº 794/PARAGUAI)}

Em razão da aceitação universal do princípio da inextraditabilidade de delinquentes políticos, princípio este consagrado nas mais variadas normas internacionais e nas Cartas Magnas de diferentes Estados, o que se verifica, na atualidade, é que muitos Estados, com o pretexto de garantir a punição do reclamado que cometeu determinado crime em seu território, solicita a extradição com base em delitos puníveis pelo direito comum, embora na realidade exista uma situação de perseguição política.

Ante a verificação de tal situação, o Ministro Sepúlveda Pertence desenvolveu a tese da extradition politique deguisée no Brasil, a partir da apresentação de um minucioso trabalho publicado nos Anais da VIII Conferência Nacional da OAB, em 1980. Isso porque, para o jurista, uma das piores formas de perseguição política "é a que se esconde, particularmente nos períodos pós-revolucionários, sob a aparência legal dos processos forjados a propósito de delitos comuns, gerando, na esfera internacional, preocupação com a chamada extradição política disfarçada" (PERTENCE, 1980, p. 67).

Dessa forma, visando melhor desenvolver o conceito no Brasil, o ministro buscou apresentar a tese e seu desenvolvimento no ordenamento jurídico nacional e internacional, tendo concluído que a extradição política disfarçada encontra-se configurada quando

[...] as circunstâncias demonstrem que a persecução formalmente desencadeada por imputação de delitos comuns dissimula o propósito de perseguir inimigos políticos ou, pelo mesmo, evidenciem que a posição política do extraditando, na conjuntura real do Estado requerente, influirá desfavoravelmente no seu julgamento (PERTENCE, 1980, p. 67).

É importante frisar que a doutrina da extradição política disfarçada foi desenvolvida precipuamente na Europa, tendo sido incorporada pela Declaração Universal de Direito Humanos, a qual, em seu artigo 14, expressamente prevê a possibilidade de o direito de asilo poder ser invocado "em caso de perseguição legitimamente motivada por crimes de direito comum ou por atos contrários aos objetivos e princípios das Nações Unidas”.

Em que pese seu maior desenvolvimento no âmbito europeu, denota-se que o princípio também se encontra incorporado explicitamente ao sistema continental latino-americano desde o Código de Bustamante, que previa em seu art. 356 a impossibilidade de concessão da extradição "se a petição de entrega foi formulada, de fato com o fim de se julgar ou castigar o 
acusado por um delito de caráter político". Essa regra de inextraditabilidade no caso de pedido de extradição política disfarçada possui força obrigatória para o Brasil, encontrando-se prevista no art. 23 do Pacto de São José da Costa Rica desde 1969:

Art. $23, \S 8^{\circ}$. Em nenhum caso o estrangeiro pode ser expulso ou entregue a outro país, seja ou não de origem, onde seu direito à vida ou a liberdade pessoal esteja em risco de violação por causa da sua raça, nacionalidade, religião, condição social ou de suas opiniões políticas.

A origem dessa regra, a qual prega pela concessão de asilo político ao invés de se determinar a extradição, remonta-se ao desenvolvimento do princípio do non refoulement no cenário internacional, pelo qual a vítima de perseguição em razão de suas ideias e posições políticas não deve ser enviada de volta para o país que a persegue (TIBURCIO; BARROSO, 2001).

Como ressaltado pelo jurista Sepúlveda Pertence ao tratar do direito de asilo, relacionando este com a problemática da extradição política disfarçada, o direito de asilo político não é relacionado ou subordinado à existência de uma persecução formal por delitos políticos, mas sim a uma situação de fato de perseguição política (PERTENCE, 1980). É nesse sentido que se justifica a denegação do pedido de extradição no caso de se verificar a existência de uma perseguição política disfarçada, ante a verificação, no caso concreto, de que de fato há uma perseguição política, mesmo que no caso não tenha havido o cometimento de crime de cunho eminentemente político.

No Brasil, em que pese o desenvolvimento da tese desde a década de 1980, e de ter-se tecido algumas considerações esparsas com relação à mesma em alguns julgados importantes, como no caso do pedido de extradição do General Alfredo Stroessner ao Paraguai (Extradição $n^{\circ} 524$ ), denota-se que apenas houve um caso em que a Supremo Tribunal Federal reconheceu a existência de extradição política disfarçada. Trata-se da Extradição no 794 , conhecida como Caso Oviedo, a qual é a seguir apresentada ante a importância de referido caso para o desenvolvimento da tese da extradition politique deguisée, podendo-se evidenciar na hipótese uma pormenorizada análise pelo Supremo Tribunal Federal das circunstâncias em que foi formulado o pedido de extradição para o reconhecimento dos delitos praticados como políticos e não meramente comuns, em contrário do afirmado pelo governo paraguaio.

No caso, o Governo do Paraguai solicitou a extradição de Lino Cesar Oviedo Silva, acusando-o de participar da prática dos crimes de homicídio doloso, lesão corporal grave e associação criminosa, os quais resultaram na morte do Vice-Presidente da República do 
Paraguai à época, Jesus Argaña Ferraro, e de seu guarda-costas, Francisco Barrios Gonzalez, bem como em lesões corporais graves em seu motorista, Victor Raul Barrios Rey.

O caso ficou conhecido como "Caso Argaña", tendo sido descrito pela autoridade governamental como uma emboscada perpetrada em via pública, quando quatro pessoas, supostamente sob a instigação do extraditando, cercaram o veículo que transportava o então Vice-Presidente e contra ele efetuaram diversos disparos de armas de fogo.

Após, o Ministro da Justiça do Paraguai, encaminhou ao STF informações complementares relativas a fatos novos, imputando ao extraditando a responsabilidade pelos fatos conhecidos como "Caso da Praça", acusando-o de ter incitado seus seguidores a praticaram os fatos ocorridos.

Na hipótese, após o assassinato do então Vice-Presidente, populares travaram intensos debates no local, manifestantes de diferentes facções políticas, estudantes, trabalhadores e outros cidadãos, clamando pela defesa da ordem democrática no país. De um lado, encontravam-se os anti-oviedistas, integrados pelos chamados "Jovens pela Democracia", os quais atribuíam a Oviedo a autoria do atentado contra o Vice-Presidente, enquanto do outro lado encontravam-se simpatizantes do movimento União Nacional de Colorados Éticos UNACE, fundado pelo extraditando, que o defendiam da imputação. Após a deliberada retirada de policiais do local, franco-atiradores não identificados passaram a disparar contra os cidadãos, o que resultou na morte de sete jovens e centenas de feridos.

Diante dos fatos narrados, foram imputados ao extraditando a prática dos crimes de homicídio doloso, lesão corporal e associação criminosa no Caso Argaña, e dos crimes de homicídio doloso com perfídia e premeditação, lesão grave, instigação criminosa e associação criminosa no Caso da Praça.

Analisando primeiramente o Caso da Praça, o Ministro Relator denegou a extradição por verificar que apesar do cometimento tanto de crimes políticos quanto comuns, o aspecto político predominou, impedindo a extradição. Como ressaltado

As consequências penais do crime comum que seguiram aos acontecimentos não podem, no caso, sobrepor-se ao fato essencialmente político. Não me parece razoável atribuir-se ao extraditando responsabilidade pessoal pelos delitos comuns, apenas a partir da ação de seus partidários [...]. Infere-se que os fatos descritos no pedido de extradição, ocorridos em época de intensa conturbação social, atentam, de forma predominante, contra a ordem política do Estado. Os delitos atribuídos ao extraditando, por isso mesmo, caracterizam-se como complexos, revestidos de clara prevalência política, de modo que é inviável o deferimento da extradição nesta parte (BRASIL. Supremo Tribunal Federal, 2001, p. 26). 
Já quando da análise do Caso Argaña, de maior importância para o desenvolvimento deste trabalho, o Ministro Relator do processo denegou o pedido de extradição, em que pese a atrocidade dos fatos, ante a constatação de que se tratava de evidente hipótese de pedido de extradição política disfarçada.

Verificou-se que, do ponto de vista formal, os fatos narrados e as imputações formuladas não conduziam à conclusão de que se tratava de crime político. Ainda, como pontuado pelo Ministro Relator, mesmo que admitida a finalidade política concorrente, já que o extraditando e a vítima principal eram importantes líderes nacionais, haveria que se concluir pela predominância de violações penais comuns, o que não impediria a extradição, ante a aplicação da teoria da prevalência ${ }^{4}$.

No entanto, do ponto de vista material, ressaltou que era possível vislumbrar na hipótese evidente pedido de extradição política disfarçada, visto que o intento do Governo Paraguaio não era simplesmente aplicar a justiça criminal em seu aspecto ordinário, mas sim condenar o extraditando pelo cometimento de crime político.

Para embasar seu Voto e demonstrar o caráter político do pedido, o Ministro Relator recorreu, primeiramente, ao contexto histórico em que os fatos foram praticados, para o fim de demonstrar seu desenvolvimento em um contexto de conturbação política no país.

Nesse sentido, ressaltou que o extraditando, desde a queda da Ditadura do General Alfredo Stroessner, exercia o Comando Geral do Exército do país, cargo que continuou a ocupar ainda após a eleição do primeiro presidente civil, o Sr. Juan Carlos Wasmosy. Ante o governo insatisfatório do presidente eleito e o aumento do apoio a Oviedo, este foi acusado de tentativa de empreender um golpe em abril de 1996, o que resultou na sua condenação a dez anos de prisão por um Tribunal Militar.

Inviabilizada sua candidatura à Presidência, em seu lugar e com seu apoio foi eleito como Presidente Raul Cubas, o qual libertou Oviedo da Prisão. Parlamentares da oposição, entretanto, irresignados com tal determinação, instaram o Presidente a recolher o extraditando à prisão, tendo seu pedido, contudo, sido recusado pelo governo, acirrando os ânimos dos oponentes.

\footnotetext{
${ }^{4}$ A teoria da prevalência procura conciliar as teorias que entendem que os delitos políticos relativos constituem infrações de direito comum com as teorias que consideram que tais delitos são em todo e qualquer caso políticos. Segundo a teoria da prevalência, admite-se a extradição quando prevalece o crime comum, ao mesmo tempo em que a prevalência do crime político implica a impossibilidade de extradição. Impõe-se, dessa forma, a avaliação do caso para aferir qual dos elementos predominam no caso concreto, para assim verificar a possibilidade ou não de extradição.
} 
É nesse cenário que em 23 de março o Vice-Presidente, Argaña é assassinado; três dias depois eclode o Caso da Praça; Cubas renuncia ao mandato e busca asilo no Brasil e em seu lugar assume o Presidente do Congresso Nacional, o Senador Luis González Macchi, antioviedista; e o Ministro da Defesa oferece recompensa de mil dólares pela captura de Oviedo.

Tais acontecimentos, segundo o Ministro Relator, demonstraram a animosidade do governo paraguaio para com o extraditando, diante da forte liderança que esse exercia no país, Oviedo constituindo-se como o "maior risco à hegemonia do atual grupo político dominante no Paraguai e o mais importante adversário no cenário de futuras eleições" (BRASIL. Supremo Tribunal Federal, 2001, p. 30).

O STF, então, concluiu que "cuida a espécie de pedido de extradição que, especialmente no Caso Arganã, embora sob o aparente rótulo de crime comum reveste-se na verdade de todas as características de crime político" (BRASIL. Supremo Tribunal Federal, 2001, p. 30). Isso porque, apesar de terem sido imputados apenas delitos comuns ao acusado, restou evidente, pelas circunstâncias do caso, que na realidade havia um nítido objetivo de perseguição política.

Ainda, o caráter político camuflado também restou evidenciado, segundo o Ministro Maurício Corrêa, ante o fato de os mandados de prisão expedidos partirem de meras ilações e conjecturas, sem nenhuma base probatória; de o indiciamento do extraditando e o decreto de prisão preventiva partirem de magistrado que depois se declarou impedido; e de todos os corréus terem sido colocados em liberdade seja pela certeza da não-participação no crime, seja pela falta de provas consistente, apenas tendo-se mantido a prisão ordenada contra Oviedo.

Assim, assentou-se que "verificando o tratamento desigual dispensado ao extraditando, a manutenção do decreto de sua prisão ratifica e reforça a convicção de que a hipótese caracteriza mesmo extradição política disfarçada" (BRASIL. Supremo Tribunal Federal, 2001, p. 37).

Da análise da Extradição no 794/Paraguai e das justificativas utilizadas pelos Ministros do Supremo Tribunal Federal, evidencia-se a preocupação do Tribunal em atender os ditames constitucionais e o disciplinado pelo ordenamento jurídico internacional. Isso porque, o que se busca é verificar se o pedido formulado pelo Estado solicitante efetivamente preenche todos os requisitos para a concessão da extradição, ou se, no caso concreto, trata-se de solicitação camuflada, em que se busca a extradição do reclamado em razão do cometimento de delito com caráter predominantemente político, hipótese na qual, conforme consagrado tanto na legislação 
nacional quanto no ordenamento jurídico internacional, implicaria imperativamente a denegação do pedido.

Há de se ressaltar, consoante o afirmado pelo Ministro Celso de Mello, que da estipulação constitucional como direito fundamental da impossibilidade de extradição ante o cometimento de crime político "emerge, nítido, em favor do estrangeiro, um direito público subjetivo, oponível ao próprio Estado e de cogência inquestionável. Há nesse preceito, uma insuperável limitação constitucional ao poder de extraditar do Estado brasileiro" (BRASIL. Supremo Tribunal Federal, 1990, p. 25).

Tratando-se de um direito público subjetivo, de uma inequívoca limitação constitucional ao poder de extraditar, deve ser denegado o pedido de extradição, inclusive nos casos em que, a primeira vista não se percebe o caráter político, mas a partir da análise de todo o contexto em que formulado o pedido evidencia a preponderância do caráter político do delito cometido e das imputações formuladas pelo Estado Solicitante.

\section{CONCLUSÃO}

A inextraditabilidade de agentes acusados do cometimento de crimes com nítido caráter político decorre, na sua essência, da impossibilidade de ingerência de um Estado nas questões políticas de outro, além da necessidade de se reconhecer o pluralismo político, a possibilidade de legítima divergência ideológica, como exercício da democracia, e de se conferir a todo e qualquer cidadão um julgamento imparcial pelos delitos a ele imputados.

A origem dessa regra ainda decorre do desenvolvimento do princípio do non refoulement (princípio da não devolução) no cenário internacional de pessoa perseguida em razão de suas convicções políticas, filosóficas ou religiosas.

É certo que a estipulação de um conceito definitivo e universalmente aceito de crime político não é uma tarefa fácil, mormente ante o fato de sua definição depender mais da prevalência de uma ideologia política, variando no tempo e no espaço. Apesar disso, no Brasil a doutrina e jurisprudência majoritária defende a necessidade de se levar em consideração, para a conceituação de crime político, tanto o bem jurídico lesado pelo crime quanto a intenção do agente ao praticar a conduta.

O fato de se levar em consideração referidos aspectos, pois permite a extensão, quando da análise do pedido de extradição, do caráter de crime político a crimes comuns praticados pelo agente infrator, permitindo, consequentemente, a denegação da extradição quando 
verificada a ocorrência de pedido de extradição política disfarçada, esta concebida, consoante o ensinamento do Ministro Sepúlveda Pertence, como uma das piores formas de perseguição política, já que se reveste de aparência legal, quando na realidade possui o propósito principal de se perseguir inimigos políticos do Estado.

A análise do processo de Extradição no 794 e das justificativas utilizadas pelos Ministros do Supremo Tribunal Federal para a denegação da extradição por se verificar hipótese de extradição política disfarçada, demonstram a preocupação dos juristas brasileiros em combater toda e qualquer forma perseguição política, mesmo que esta seja camuflada, de modo se observar as garantias fundamentais consagradas pela Constituição Federal e pelas normas internacionais que regem a matéria.

Em vista disso, se garante aos estrangeiros o respeito a um direito público subjetivo inquestionável, qual seja, da denegação da extradição ante a verificação do caráter político do pedido, direito este que remonta aos ideais de liberdade política e ideológica consagrados desde o século XVIII e hoje considerados de essencial importância para a garantia de direitos humanos e fundamentais protegidos pela ordem internacional e pelas Constituições nacionais.

\section{REFERÊNCIAS}

ACCIOLY, Hildebrando. Manual de Direito Internacional Público. 22 ed. São Paulo: Saraiva, 2016.

BRASIL. Supremo Tribunal Federal. Extradição n. 1008/Colômbia. Tribunal Pleno. Relator Ministro Gilmar Mendes. Relator para acórdão: Ministro Sepúlveda Pertence. Julgado em 21 de março de 2007. Disponível em: <http://redir.stf.jus.br/paginadorpub/paginador.jsp?docTP= AC\&docID=479118>. Acesso em: 05 de novembro de 2016.

Supremo Tribunal Federal. Extradição n. 794/Paraguai. Tribunal Pleno. Relator Ministro Maurício Corrêa. Julgado em 17 de dezembro de 2001. Disponível em: < http://redir. stf.jus.br/paginadorpub/paginador.jsp?docTP=AC\&docID=324957>. Acesso em: 05 de novembro de 2016.

Supremo Tribunal Federal. Extradição n. 700/Alemanha. Tribunal Pleno. Relator Ministro Octavio Galotti. Julgado em 04 de março de 1998. Disponível em: < http://redir.stf.j us.br/paginadorpub/paginador.jsp?docTP=AC\&docID=324888>. Acesso em: 05 de novembro de 2016.

Supremo Tribunal Federal. Extradição n. 524/Paraguai. Tribunal Pleno. Relator Ministro Celso de Mello. Julgado em 31 de outubro de 1990. Disponível em: < http://redir.stf. jus.br/paginadorpub/paginador.jsp?docTP=AC\&docID=324746>. Acesso em: 05 de novembro de 2016. 
Supremo Tribunal Federal. Extradição n. 493/Argentina. Tribunal Pleno. Relator Ministro Sepúlveda Pertence. Julgado em 04 de outubro de 1989. Disponível em: < http://redi r.stf.jus.br/paginadorpub/paginador.jsp?docTP=AC\&docID=324725>. Acesso em: 05 de novembro de 2016.

Supremo Tribunal Federal. Extradição n. 417/Argentina. Tribunal Pleno. Relator Ministro Alfredo Buzaid. Julgado em 20 de maio de 1984. Disponível em: <http://redir.stf.jus. br/paginadorpub/paginador.jsp?docTP=AC\&docID=324655>. Acesso em: 05 de novembro de 2016.

Supremo Tribunal Federal. Extradição n. 347/Peru. Tribunal Pleno. Relator Ministro Thompson Flores. Julgado em 28 de maio de 1980. Disponível em: <http://redir.stf.jus.br/pagi nadorpub/paginador.jsp?docTP=AC\&docID=324613>. Acesso em: 05 de novembro de 2016.

CONTESSA, Mariana Camargo. A vedação à extradição por crime político. 2011. Monografia (Graduação em Ciências Jurídicas e Sociais). Universidade Federal do Rio Grande do Sul, Porto Alegre, 2011.

FERREIRA, Pinto. Comentários à Constituição brasileira. São Paulo: Saraiva, 1989. v. 1.

FRAGOSO, Heleno Cláudio. Lições de Direito Penal: parte geral. 4 ed. Rio de Janeiro: Forense, 1980.

HUNGRIA, Nélson. Comentários ao Código Penal. 3 ed. Rio de Janeiro: Forense, 1955. v. 1.

LÉVY-BRUHL, Henri. Les délits politiques: recherche d'une définition. Revue Française de Sociologie, Paris, v. 5, p. 131-139, 1964.

MACABU, Adilson Vieira. A extradição: sua evolução na doutrina e na prática internacional. Revista de Ciência Política, Rio de Janeiro, 23 (2), p. 143-189, maio/ago. 1980.

MELLO, Celso Duvivier de Albuquerque. Curso de Direito Internacional Público. 14 ed. Rio de Janeiro: Renovar, 2002.

MOTTA, Candido Nazianzeno Nogueira da. O crime político. Revista da Faculdade de Direito da Universidade de São Paulo, São Paulo, v. 26, p. 19-39, 1930.

PERTENCE, José de Paulo Sepúlveda. Liberdade e direito de asilo. Anais da VIII Conferência Nacional da $O A B$, Manaus, p. 57-80, 1980.

PRADO, Luiz Regis; CARVALHO, Erika Mendes de. Delito político e terrorismo: uma aproximação conceitual. Revista dos Tribunais, São Paulo, v. 771, 2000.

REZEK, José Francisco. Direito internacional público: curso elementar. 13 ed. São Paulo: Saraiva, 2011. 
TIBURCIO, Carmen; BARROSO, Luiz Roberto. Algumas questões sobre a extradição no direito brasileiro. Revista de Informação Legislativa, Brasília, n. 150, p. 173-194, abr.jun. 2001.

ZANOTTO, Felipe. O conceito de crime político como instrumento do controle penal da atividade política. 2015. Monografia (Graduação em Direito). Universidade Federal de Santa Catarina, Centro de Ciências Jurídicas, Santa Catarina, 2015. 